Nama : Timur Damar Piyangka (130117122)

\title{
Ekonomi Sumber Daya Manusia
}

$K \boldsymbol{P}: A$

REVIEW ARTIKEL

\section{Indonesia's Efforts to Achieve Globally Competitive Human Resources}

International Journal of Humanities and Social Science Invention (IJHSSI)

ISSN (Online): 2319 - 7722, ISSN (Print): 2319 - 7714

www.ijhssi.org ||Volume 7 Issue 08 Ver. III ||August. 2018 || PP $01-06$

\section{INTRODUCTION}

Dalam tahun-tahun terakhir ini Indonesia mengalami peningkatan dalam sector ekonomi, yakni sebsar 5\% dan bahkan terus berkembang diatas 5\%. Dengan perkembangan ekonomi di Indonesia yang bisa dikatakan cukup pesat, pemerintah berkomitmen akan membangun sector atau industry Manufaktur yang lebih baik lagi. Perkembangan system informasi yang sangat pesat, yang saat ini bisa dikatakan mencapai Industri 4.0 dimana dalam industry ini dibutuhkan konektivitas dan interaksi melalui teknologi yang berintegritas.

Gelombang keempat dari revolusi industry ini ditandai dengan penggunaan teknologi informasi, kecerdasan buatan, serta lebih banyak menggunakan mesin otomatis. Pada era ini dan juga era dimasa depan keunggulan kompetitif telah menjadi kebutuhan utama untuk para pengusaha dalam bersaing di pasar global. Dalam kondisi seperti ini persaingan tentunya akan menjadi lebih ketat, karena setiap pelaku usaha dapat bersaing secara bebas di dunia luar atau menjual produknya ke negara lain dengan sangat mudah.

Dalam situasi seperti ini kita dihadapkan dan diharuskan untuk selalu melakukan inovasi yang tidak henti-hentinya. Dalam rangka untuk melakukan inovasi terus-menerus salah satu penentunya adalah kesiapan dunia usaha dalam membangun serta memeilih sumber daya manusia yang baik dan dapat bersaing dengan dunia luarIndonesia membutuhkan sumber daya manusia yang baik serta unggul mengingat adanya gangguan teknologi yang menandai revolusi industry 4.0 yang telah mengubah banyak cara berfikir salah satunya adalah banyaknya perusahaan yang lebih memilih teknologi sebagai salah satu pekerjanya.

\section{LITERATUR REVIEW}

Secara umum produktivitas karyawan berbanding lurus dengan daya saing yang tinggi dalam organisasi secara keseluruhan dalam menghadapi pesaing yang bisnis. Karena produktivitas karyawan sangat terkait dengan lingkungan pekerjaan,tingkat kepuasan karyawan terhadap organisasi perusahaan, yang meliputi gaji yang baik, jaminan karir yang lebih baik, serta manfaat dan fasilitas yang ditawarkan oleh perusahaan. 
Perusahaan yang bisa digolongkan perusahaan yang baik adalah perusahaan yang kompetitif dan adaptif atau dapat dengan cepat menyesuaikan diri dengan era atau lingkungan yang baru. Pada masa ini dimana keadaan sangat sering berubah-ubah perusahaan yang memiliki sifat adaptif atau yang dapat menyesuaikan diri dengan cepat adalah perusahaan yang akan terus bertahan di era industri 4.0 yang menuntut setiap perusahaan dapat adaptif dengan informasi serta perkembangan teknologi.

Dalam upayanya yaitu menyesuaikan diri dengan lingkungan yang baru, perusahaan biasanya melakukan berbagai upaya atau cara yaitu dengan mengubah metode-metode lama dan menggantinya dengan metode baru yang lebih efisien. Cara-cara yang baru ini membutuhkan trnasformasi sumberdaya yang baru serta transformasi bisnis yang baru.

\section{RESEARCH METHOD}

Dalam penelitian ini dikategorikan dikategorikan sebagai penelitian kualitatif dengan positif paradigma yaitu suatu penelitian yang dilakukan dengan menganalisis sumber daya manusia dari sisi ekonomi. Dalam penelitian ini berusaha menafsirkan suatu kejadian dari sudut pandang berdasarkan interpretasi dari kejadian yang terjadi di lingkungan organisasi perusahaan.

Analisis data ini diharapkan dapat menyajikan data yang akurat, ini berarti bahwa validasi dari keakuratan data dilakukan secara bertahap, dimulai dari pengadaan data mentah yang selanjutnya diolah untuk menganalisis yang kemudian akan menjadi sebuah tema serta deskripsi suatu kejadian.

\section{DISCUSSION}

Skor Indeks Pembangunan Manusia di Indonesia pada tahun 2017 menyentuh angka 70,81. Dengan skor sebesar 70,81 ini bisa dikatakan kategori IPM tinggi, karena skor IPM Indonesia berada diatas angka 70,00. Namun dengan predikat IPM yang cukup baik terdapat 18 provinsi yang berkatagori HDI menengah atau rendah, seperti Papua Barat, dan Nusa Tenggara Timur. Penyebab dari rendahnya HDI dibeberapa provinsi ini adalah akses yang sulit untuk masyarakat menuju tempat pendidikan atau sekolah, serta tingkat kematian bayi yang cukup tingi. Hal ini bisa jiga disebabkan karena kebijakan pemerintah yang belum difokuskan pada pengembangan kualitas sumber daya di Indonesia.

Masalah kemiskinan yang terjadi di Indonesia juga tidak terlepas dari kualitas sumber daya manusia yang rendah. Masalah kemiskinan juga telah menjadi masalah serius yang dihadapi oleh Indonesia. Rasio ketergantungan penduduk pada tahun 2000 adalah sebesar 53,8\% dan pada tahun 2017 menurun di angka 48,1\%. Hal ini menunjukan bahwa penurunan rasio ketergantungan selama 17 tahun tidak linier dengan penurunan tingkat kemiskinan sebanyak 26.580.00 orang pada bulan September 2017.

Hal yang juga sangat mengkhawatirkan tentang rendahnya kualitas sumber daya manusia di Indonesia adalah rendahnya prestasi pendidikan formal serta kompetensi dasar yang terbilang rendah. Hal ini didukung dengan minimnya akses pendidikan serta kualitas pendidikan yang tidak terlalu baik atau kurang dari kata baik. Jauhnya kesenjangan pendidikan 
yang terjadi di Indonesia juga menjadi factor utamanya. Peningkatan kualitas pengajaran dan pembelajaran juga masih rendah, yaitu hanya untuk meningkatkan nilai hasil belajar. Jadi dapat dikatakan peningkatan kualitas belajar dan mengajar tidak memberikan dampak terhadap perilaku dan pola pikir.

Setiap individu harus dibiasakan untuk mengembangkan keunikan dan kelebihan dalam dirinya untuk mengembangkan sifat yang lebih unggul. Perlu dipahami bahwa inovasi tidak berarti harus menemukan produk yang super unik, tetapi dapat dilakukan dengan memiliki aliansi strategis, sinergis dan berkolaborasi dengan mitra bisnis yang baik.

Pemimpin perusahaan memiliki tugas untuk mendorong individu yang berbeda untuk mewujudkan visi dan misinya masing-masing. Pemimpin perusahaan besar dan menengah di Indonesia yang sadar akan semakin ketat peta persaingan bebas dan mencoba untuk mendorong sumber daya manusia untuk siap bersaing di tingkat global, seperti PT. Pertamina yang menerapkan Sistem Manajemen Kinerja di mana karyawan memiliki kesempatan untuk menyampaikan aspirasi mereka melalui program pembinaan, hari dialog, dan sesi umpan balik. Selanjutnya, pemimpin global dan pemenuhan pemain global dapat dilakukan melalui program pemimpin bisnis.

Pemimpin perusahaan akan lebih diuntungkan ketika memilih karyawan yang berbakat dengan lingkungna kerja yang kondusif. Sebuah organisasi perusahaan harus terus mengubah, baik dalam mencari lompatan bisnis yang inovatif secara terus menurus. Dalam pandangan karyawan, uang adalah penting, tetapi "arti kerja" sebenarnya jauh lebih berharga. Untuk mendapatkan "arti kerja" perlu memperbanyak hubungan dengan orang lain. Dengan demikian, organisasi perlu menemukan metode pembelajaran diri didorong yang dapat menarik karyawan, pelatihan dan universitas perusahaan tampaknya menjadi tempat belajar yang sempit untuk menampung karyawan yang ingin belajar dalam cara yang santai.

\section{CONCLUSION}

Indonesia sangat membutuhkan sumbe daya manusia yang lebih baik, untuk mengatasi serta menghadapi revolusi industry 4.0, yang selalu menuntut untuk bisa berinovasi serta memiliki pemikiran yang terbuka akan teknologi dan informasi. Jika Indonesia tidak segera menangani permasalahn sumberdya manusianya, maka dimasa yang akan datang perang dalam masalah bakat akan menjadi masalah utama oleh para pemimpin perusahaan dalam menghadapi era ekonomi global dan digital. Maka peran pemimpin akan lebih penting lagi untuk mengubah pola pikir karyawan dalam kaitan dengan manajemen perusahaan dan juga kinerja setiap individu. Bakat setiap sumber daya juga harus mampu berkolaborasi dalam menerapkan kompetensi untuk mendapatkan hasil yang lebih optimal, serta perusahaan diharapkan mampu membangun system strategi yang lebih baik.

\section{References}

Tayibnapis, A. Z., Wuryaningsih, L. E., \& Gora, R. (2018). Indonesia's Efforts to Achieve Globally Competitive Human. International Journal of Humanities and Social Science Invention (IJHSSI), 7(8), 01-06. 